\title{
Yield and Quality of Sugar Cane as Infulenced by Ridge Width, Seeding and Nitrogen Fertilizer Rates Abdel-Kader, E. M. A. ${ }^{1}$ and A. M. Abdel-Aal ${ }^{2}$ \\ ${ }^{1}$ Agronomy Department, Fac. Agric. , Cairo, Al-Azhar University, Nasr city, Cairo, Egypt. \\ ${ }^{2}$ Sugar Research Institute, Agriculture Research Center, Giza, Egypt.
}

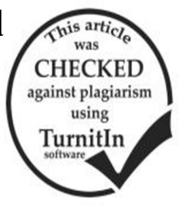

\section{ABSTRACT}

The present study was conducted at Shandaweel Agricultural Research Station, Sohag Governorate $\left[26.5013^{\circ} \mathrm{N}, 31.7651^{\circ} \mathrm{E}\right]$ during 2015/2016 and 2016/2017 seasons to investigate the effect of three ridge widths $(80,100$ and $120 \mathrm{~cm})$, two seeding rates (37800 and $50400 \mathrm{buds} / \mathrm{fed})$ and three nitrogen levels $(180,200$ and $220 \mathrm{~kg} \mathrm{~N} / \mathrm{fed})$ on yield and quality of sugar cane. Each experiment was carried out in split-split plot design with three replications. The results showed that planting sugarcane on ridges width at $100 \mathrm{~cm}$ apart attained a significant increase in cane stalk height, number of millable canes, cane yield/fed, as well as brix, sucrose, sugar recovery percentages and sugar yield/fed compared with those planted at 80 and $120 \mathrm{~cm}$. Significant increase in stalk diameter was recorded at $120 \mathrm{~cm}$ ridge width in both seasons. The results indicated that the two seeding rates differed significantly in cane stalk height, stalk diameter, number of millable canes, cane and sugar yields, as well as brix, sucrose percentages in both seasons. Raising $\mathrm{N}$ fertilizer rate from 180 to $220 \mathrm{~kg} \mathrm{~N} /$ fed resulted in a significant increase in cane stalk height, stalk diameter, number of millable canes, cane and sugar yields /fed in both seasons. The results indicated that the interaction effect between ridge width of $100 \mathrm{~cm}$, seeding rates of two rows (16800 of three-budded cane cuttings/fed) and fertilized by $220 \mathrm{~kg} \mathrm{~N} /$ feddan gave the highest values of cane and sugar yield /feddan. Under conditions of the present investigation, growing promising sugarcane variety G. 2003-49 in rows of $100 \mathrm{~cm}$ apart with seeding rate of 2 rows of cane cuttings ( $50400 \mathrm{buds} / \mathrm{fed}$ ) and fertilized with $220 \mathrm{~kg} \mathrm{~N} / \mathrm{fed}$ can be recommended to get the maximum cane and sugar yields/fed.

\section{INTRODUCTION}

Sugar cane (Saccharum officinarum L.) is considered the main important sugar crop in Egypt and in many countries all over the world .Sugar cane plays a prominent role for sugar production in Egypt . Recently, Egypt face a great problem concerned with the lake of sugar production to feed an increasing population .So increasing sugar production is necessary to meet demands of population. One of the approaches to increase sugar production is raising sugar cane production per unit area.

Increasing sugar production from unit area could be achieved by using adequate agriculture practices i.e. plant density, high yielding varieties and fertilization.

Row spacing has a direct effect on plant population. It plays a distinct role in the amount of solar radiation and hence, crop canopy development, which in turn affects photosynthesis and ultimately the dry matter produced by plant. El-Geddawy, et al. (2002-a) found that narrow row spacing $(100 \mathrm{~cm})$ produced higher number of millable canes, cane and sugar yields compared to 120 and/or 140 $\mathrm{cm}$ row spacing. Their results showed that the wider row spacing $(140 \mathrm{~cm})$ significantly recorded higher values for stalk height, thicker stalks, compared with those of narrower spacing of $100 \mathrm{~cm}$. El-Geddawy, et al. (2002-b) added that the widest row spacing gave the highest sucrose, and sugar recovery percentage. Raskar and Bhoi (2003) found that cane girth and number of millable canes were significantly higher with a $90-\mathrm{cm}$ intra-row spacing compared with 30 or $60-\mathrm{cm}$ intra-row spacing. Millable cane height was insignificantly affected by spacing. Rizk, et al. (2004-a) found that sucrose was insignificantly affected by the studied row distances (100, 120 and 140 $\mathrm{cm})$. Likewise, Rizk, et al. (2004-b) mentioned that the widest row distance significantly gave the thickest stalks. El-Shafai and Ismail (2006) indicated that planting sugarcane in rows spaced at $80-\mathrm{cm}$ apart attained a significant increase in cane stalk height, number of millable canes, cane and sugar yields/fed compared with 100 and $120 \mathrm{~cm}$, while sucrose, sugar recovery percentages were insignificantly affected by row spacing. Bekheet, et al. (2011) showed that planting sugarcane varieties in rows spaced at $80-\mathrm{cm}$ apart attained significant increase in cane stalk height, number of millable canes, cane yield/fed, brix, sucrose, sugar recovery percentages and sugar yield/fed compared with those planted at 100 and $120 \mathrm{~cm}$. However, they detected a significant increase in stalk diameter at 120 cm row spacing.

Crop density (number of drills of cane cuttings/furrow) could be one of the main environmental factors affecting sugarcane productivity and quality. ElSogheir (1999) noticed that seed rate (1.0, 1.5 and 2.0 drill/furrow) affected significantly stalk length, stalk diameter, cane and sugar yield, while sucrose and purity percentages were insignificantly affected. Two rows of cane cutting exceeded the other two seed rate in stalk length, cane and sugar yields. Avtar (2000) planted sugarcane cv. Coj 84, at 50000 or 70000 three-budded setts and revealed that cane yield was significantly higher with dense planting. Garside, et al. (2002) grew sugarcane with two planting densities (27000 and 81000) and two row spacings ( 0.5 and 1.5 meters). They found that there was a trend for increased yields due to dense planting. Shahid, et al. (2002) found that sugarcane established at 62500 and 75000 double-budded setts/ha showed the highest cane (73.41 and $72.63 \mathrm{t} / \mathrm{ha}$ ) and sugar (10.17 and $10.1 \mathrm{t} / \mathrm{ha})$ yields, respectively. Ahmed (2003) studied the effect of three seed rate of 25200, 37800 and 50400 buds/fed (1.0, 1.5 and 2.0 drills of cane setts) sugarcane. He found that increasing seed rate increased number of millable cans $/ \mathrm{m}^{2}$ and cane and sugar yields. However, stalk length, stalk diameter and sugar recovery percentages were insignificantly affected by seed rate. El-Geddawy, et al. (2015) found that dual drilling of cane seed sets increased number of millable canes, cane and sugar yield.

Nitrogen is among the principal factors limiting yield of sugar cane production.

Several investigators reported that cane yield was increased with increasing nitrogen level. Shafshak, et al. (2001) found that increasing N-level from 150 to $190 \mathrm{~kg}$ $\mathrm{N} /$ fed significantly increased stalk height and diameter. 
Insignificant difference was detected in stalk height between 190 and $230 \mathrm{~kg} \mathrm{~N} /$ fed. Nitrogen level had insignificant effect on sucrose and reducing sugar content. Ahmed (2003) reported that the application of $240 \mathrm{~kg}$ $\mathrm{N} / \mathrm{fed}$ gave the highest values of the number of millable canes $/ \mathrm{m}^{2}$, millable cane length, cane and sugar yields/fed. Tiwari, et al. (2004) tested the effect of three $\mathrm{N}$ levels given to sugarcane (100, 150 and $200 \mathrm{~kg} \mathrm{~N} / \mathrm{ha}$ ). They noticed that increasing $\mathrm{N}$ level increased number of tillers, millable canes, yield components and cane yield. Sucrose $\%$ was deteriorated when $\mathrm{N}$ level was further than 150 $\mathrm{kg} / \mathrm{ha}$. Azzazy, et al. (2005) supplied sugarcane with three $\mathrm{N}$ levels $(180,210$ and $240 \mathrm{~kg} \mathrm{~N} / \mathrm{fed})$. They demonstrated that increasing $\mathrm{N}$ level up to $240 \mathrm{~kg} \mathrm{~N} /$ fed resulted in a significant increase in stalk height, stalk diameter and cane yield of the plant cane, but decreased sucrose and sugar recovery percentages. Sugar yield was insignificantly affected by $\mathrm{N}$ levels. Ismail, et al. (2008) found increasing $\mathrm{N}$ levels up to $232.5 \mathrm{~kg} \mathrm{~N} /$ fed significantly increased number of millable canes, cane and sugar yields/fed. Stalk length and quality traits were insignificantly affected by $\mathrm{N}$ levels. Mokadem, et al. (2008) reveled that increasing N levels attained a positive and significant effects on stalk height, millable canes/fed, cane yield/fed, sugar yield/fed and sugar recovery\%. Bekheet, et al. (2011) stated that raising $\mathrm{N}$ fertilization level from 170 to $200 \mathrm{~kg} \mathrm{~N} /$ fed for the plant cane and from 185 to $215 \mathrm{~kg} \mathrm{~N} /$ fed for the $1^{\text {st }}$ ratoon crop resulted in a significant increase in cane stalk height, stalk diameter, number of millable canes, cane and sugar yield /fed. Abd El-Aal et al. (2015) reported that increasing $\mathrm{N}$ fertilization level from 180 to 210 and $240 \mathrm{~kg}$ $\mathrm{N} /$ fed. resulted in a significant increase in stalk diameter and cane yield of plant cane .On the contrary, sucrose and sugar recovery percentage significantly decreased as the applied N-dose was increased.

The objective of this investigation was to find out the best combination of the studied factors to attain the maximum cane and sugar yields under conditions of Sohag Governorate, Egypt.

\section{MATERIALS AND METHODS}

The present investigation was carried out at Shandaweel Agricultural Research Station, Sohag Governorate $\left[26.5013^{\circ} \mathrm{N}, 31.7651^{\circ} \mathrm{E}\right.$ ] during 2015/2016 and 2016/2017 seasons. The experiment treatments were as follows :

\section{1- Ridge width} $120 \mathrm{~cm})$,

Three ridge widths were studied i.e. $(80,100$ and

\section{2- Seeding rates}

Two seeding rates, i.e. 37800 and 50400 buds/fed, the two seeding rates were obtained by planting 12600 and 16800 of three-budded seed setts/fed which were arranged in furrows as 1.5 and 2.0 rows/furrow, respectively.

\section{3- Nitrogen fertilizer rates}

Three $\mathrm{N}$ rates were applied i.e. $(180,200$ and 220 $\mathrm{kg} \mathrm{N} / \mathrm{fed}$. in both seasons). Nitrogen fertilizer in the form of Urea, $46 \% \mathrm{~N}$ was added in two equal doses. The one was applied 50 days after planting, preceded with hoeing. The $2^{\text {nd }} \mathrm{N}$-dose was added one month after the $1^{\text {st }}$ one.
A split-split plot design with three replications was used, where ridge widths were allocated in the main plots, the sub plots were assigned for the two seed setts/fed, while the three $\mathrm{N}$ rates were distributed in the sub-sub plots. The sub-sub-plot area was $60 \mathrm{~m}^{2}$ (including 15, 12 and 10 rows in case of spacing 80, 100 and $120 \mathrm{~cm}$ spacings, respectively and $5 \mathrm{~m}$ in length).

Sugarcane was sown as a plant cane in the first week of March using the promising variety G. 2003-49. Canes were harvested at age of 12 months. Soil mechanical and chemical analyses of the experimental site showed that the upper $30 \mathrm{~cm}$ of the soil was clay loam $(29.4 \%$ sand, $10.4 \%$ silt and $59.6 \%$ clay) which contained $34.0,11.7$ and $210 \mathrm{ppm}$ available $\mathrm{N}, \mathrm{P}, \mathrm{K}$, respectively, with a $\mathrm{pH}$ of 7.4 Pag (1982) and Arnold (1986).

The recommended rates of $\mathrm{P}$ and $\mathrm{K}$ fertilizers were added during seed bed preparation at the rates of $30 \mathrm{~kg}$ $\mathrm{P}_{2} \mathrm{O}_{5}$ (as super phosphate, 15.5\%) and $48 \mathrm{~kg} \mathrm{~K}_{2} \mathrm{O}$ (as potassium sulphate $48 \% \mathrm{~K}_{2} \mathrm{O} / \mathrm{fed}$, respectively. The other agricultural practices were done as recommended by Sugar Crops Research Institute.

\section{Data recorded:}

At harvest, ten plants were randomly taken to determine the following characters

1- Stalk height $(\mathrm{cm}) \quad$ 2- Stalk diameter $(\mathrm{cm})$.

Plants of the guarded rows were harvested, topped and the following parameters were recorded:

3- Number of millable canes/fed,

4- Cane yield (ton/fed)

5- Sugar yield (ton/fed), which was estimated according to the following equation:

Raw sugar production $=$ cane yield (tons/fed) $\mathrm{x}$ sugar recovery $\%$.

A sample of 20 millable cane stalks was collected immediately after harvesting, cleaned and crushed to determine the following quality traits:

6- Brix percentage (total soluble solids, TSS \%) in juice was determined using Brix Hydrometer standardized at $20 \mathrm{C}^{\circ}$.

7- Sucrose $/ 100 \mathrm{~cm}^{3}$ juice was determined using Sacharemeter according to A.O.A.C. (1995).

8- Sugar recovery percentage was calculated as follows:

Where:

Sugar recovery $\%=$ richness $\%$ x purity $\%$,

Richness $=$ (sucrose in $100 \mathrm{x}$ factor $) / 100$.

Factor $=100-[$ fiber $\%+$ physical impurities $\%+$ percent water free from sugar].

The collected data were statistically analyzed according to Snedecor and Cochran (1981). Treatment means were compared using LSD at 5\% level.

\section{RESULTS AND DISCUSSION}

\section{Stalk height:}

Data recorded in Table 1 show that increasing ridge width from 80 to 100 and to $120 \mathrm{~cm}$ led to a significant decrease in cane stalk height in both seasons. This result could be due to the intraspecific competition among cane plants for light in the dense planting, i.e. narrower ridge width. The results manifested that increasing ridge width to 100 and to $120 \mathrm{~cm}$ decreased stalk height by $(7.94$ and $13.51 \mathrm{~cm})$ and $(7.41$ and $10.53 \mathrm{~cm})$ in the first and second season, respectively, compared to sugarcane grown at 80 
$\mathrm{cm}$. These results are in consistence with those obtained by El-Shafai and Ismail (2006).

The results in Table 1 indicate that increasing planting materials from 1.5 to 2.0 rows of cane cuttings (from 12600 to 16800 of three-budded cane cuttings/fed) increased stalk height in both seasons. The results pointed out that increasing planting material from 12600 to 16800 of three-budded/setts increased stalk height appreciably by 5.71 and $6.83 \mathrm{~cm}$ in the first and second seasons, respectively. These results may be due to the intraspecific competition among plants for solar radiation of dense planting . These findings coincide with those reported by Avtar (2000).

Data presented in Table 1 clear that increasing the applied $\mathrm{N}$ rate from 180,200 to $220 \mathrm{~kg} \mathrm{~N} /$ fed led to a significant increase in stalk height. The increase in stalk height may be attributed to the role of nitrogen as an essential element in building-up plant organs and enhancing their growth. These results are in agreement with those reported by Ahmed (2003), Azzazy, et al. (2005) and Mokadem, et al. (2008).

All of the interactions among the three studied factors had insignificant influence on this traits in the second season, but the interaction between ridge widths and seeding rates was insignificant in the first season.

On the other hand, the interaction effect among ridge widths and nitrogen fertilizer rates was significant on stalk height in 2015/2016 season. Sowing sugar cane plants on ridges of $80 \mathrm{~cm}$ distance and received $220 \mathrm{~kg} \mathrm{~N} /$ Fed. gave the tallest stalk $321.77 \mathrm{~cm}$, but the shortest stalks $287.73 \mathrm{~cm}$ was recorded with sowing plants on rows of $120 \mathrm{~cm}$ distance and fertilized by nitrogen at the rate of $180 \mathrm{~kg} \mathrm{~N} / \mathrm{fed}$. as compared with other treatments in 20915/2016 season.

Table 1 .Average of stalk height and diameter $(\mathrm{cm})$ as influenced by ridge widths, seeding and nitrogen rates as

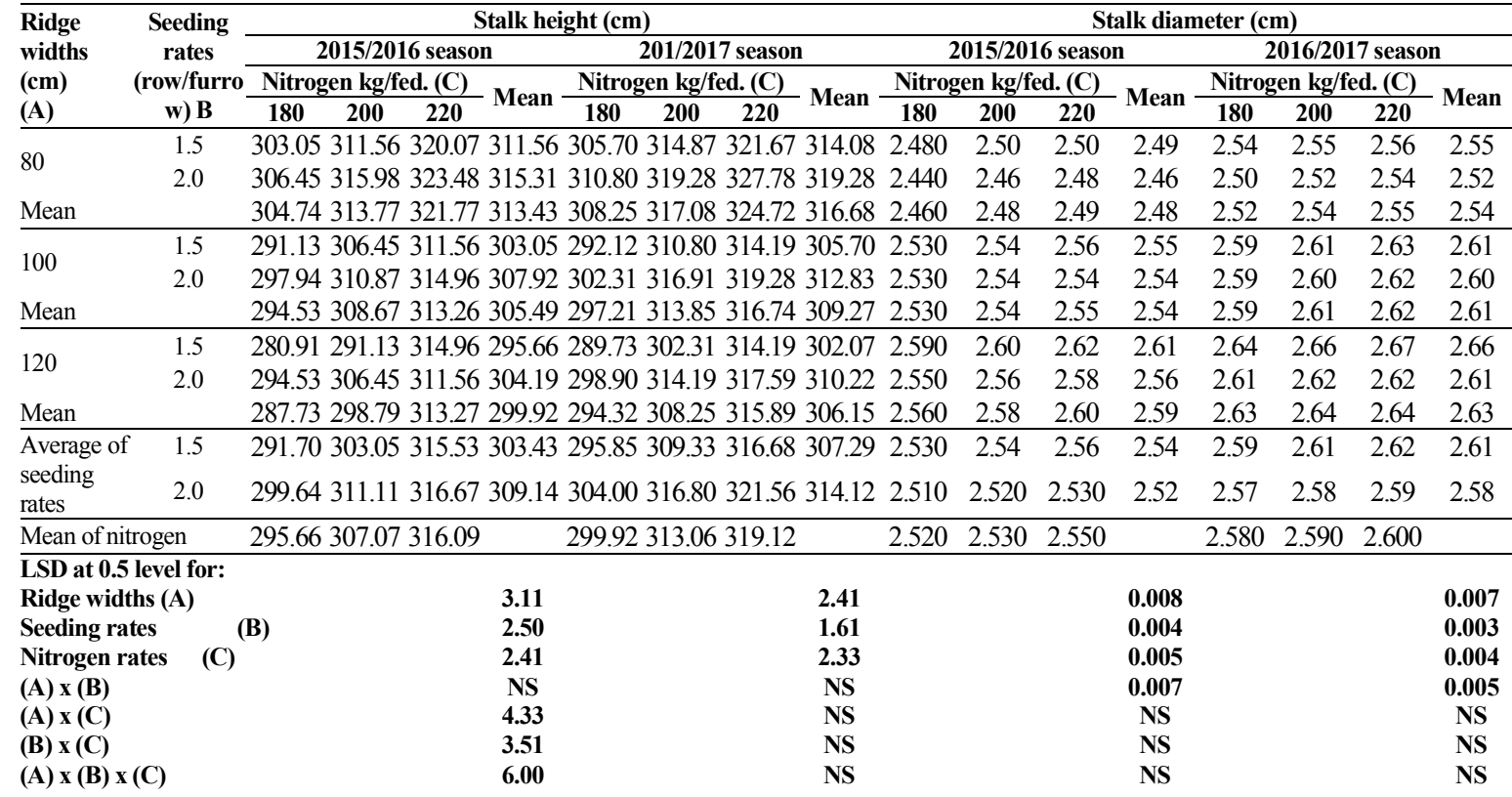

Results tabulated in Table 1 indicated that increasing planting materials from 1.5 to 2.0 rows of cane cuttings (from 12600 to 16800 of three-budded cane cuttings/fed) resulted in reduction of stalk diameter by 0.79 and $1.15 \%$ in
The interaction effect among seeding rates and nitrogen fertilizer rates was significant on stalk height in $2015 / 2016$ season. Sowing sugar cane plants by seeding rate of 2.0 rows of cane cuttings (planting material 16800 of three-budded/setts) and received $220 \mathrm{~kg} \mathrm{~N} /$ Fed. gave the tallest stalk $316.67 \mathrm{~cm}$, but the shortest stalks 291.70 $\mathrm{cm}$ was recorded with sowing plants by seeding rate of 2.0 rows of cane cuttings and fertilized by nitrogen at the rate of $180 \mathrm{~kg} \mathrm{~N} / \mathrm{fed}$. as compared with other treatments in 20915/2016 season .

The interaction effect among ridge widths, seeding rates and nitrogen fertilizer rates was significant on stalk height in 2015/2016 season. Sowing sugar cane plants on ridge width of $80 \mathrm{~cm}$, seeding rate of 2.0 rows of cane cuttings (planting material 16800 of three-budded/setts) and received $220 \mathrm{~kg} \mathrm{~N} /$ Fed. gave the tallest stalk 323.48 $\mathrm{cm}$, but the shortest stalks $280.91 \mathrm{~cm}$ was recorded with sowing plants on rows spacing of $120 \mathrm{~cm}$ by seeding rate of 1.5 rows of cane cuttings and fertilized by nitrogen at the rate of $180 \mathrm{~kg} \mathrm{~N} / \mathrm{fed}$. as compared with other treatments in 20915/2016 season .

\section{Stalk diameter:}

Data in Table 1 show a significant and gradual spacing between rows from 80 to 100 and $120 \mathrm{~cm}$ which have 2.48 and $2.54 \mathrm{~cm}, 2.54$ and $2.61 \mathrm{~cm}$ and 2.589 and $2.63 \mathrm{~cm}$ in the same respect in 2015/2016 and 2016/2017 seasons. This result may be attributed to lower intraspecific competition for nutrients, water and solar radiation among cane plants grown in wider rows, which reflected in better growth conditions, compared with those grown in narrower ones. This result is in accordance with those reported by El-Geddawy, et al. (2002-a) and Rizk (2004-b). increase in cane stalk diameter associated with widening

\section{\begin{tabular}{lll} 
well as their interactions in $2015 / 2016$ and $2016 / 2017$ seasons. \\
\hline Ridge $\quad$ Seeding
\end{tabular}}

2015/2016 and 2016/2017 seasons, respectively. These results may be attributed to the highest competition between plants caused by dense sowing which led to producing thin stalks. 
The results clear that increasing the applied $\mathrm{N}$ levels up to 200 and $220 \mathrm{~kg} \mathrm{~N} /$ fed caused a significant increase in stalk diameter in both seasons. This result may be attributed to the role of $\mathrm{N}$ element in building-up plant organs and enhancing plant growth. These results are in agreement with those reported by Ahmed (2003), Azzazy, et al. (2005) and Mokadem, et al. (2008).

All possible interactions had insignificant effect on stalk diameter, except the interaction between ridge width and seeding rate in both seasons.

However, planting sugar cane plants on rows of 120 $\mathrm{cm}$ distance and seeding rate of 1.5 rows of cane cuttings (12600 of three-budded cane cuttings/fed) produced the widest stalk 2.61 and $2.66 \mathrm{~cm}$, on the contrary, planting sugar cane plants on rows of $80 \mathrm{~cm}$ distance and seeding rate of 2 rows of cane cuttings ( 16800 of three- budded cane cuttings/fed) produced the thin stalk 2.46 and $2.52 \mathrm{~cm}$ in 2015/2016 and 2016/2017 seasons, respectively.

\section{Number of millable canes/fed and canes yield/fed:}

Data in Table 2 cleared that increasing ridge width from 80 up to $120 \mathrm{~cm}$ resulted in a significant reduction in the number of millable canes/fed by 4.53 and $4.79 \%$ and can yield (ton/fed) by 5.32 and $4.45 \%$ in 2015/2016 and 2016/2017 seasons, respectively. These results could be due that widening distance between rows to $120 \mathrm{~cm}$ decreased stalk height (Table 1 ) and number of millable canes/fed . therefore can yield (ton/fed) decreased . These results are in agreement with those mentioned by ElGeddawy, et al. (2002-a) and Raskar and Bhoi (2003) and El-Shafai and Ismail (2006).

The result presented in Table 2 indicated that increasing planting materials from 1.5 to 2.0 rows of cane cuttings (from 12600 to 16800 of three-budded cane cuttings/fed) increased in number of millable canes/fed by 3.90 and 3.00 thousand stalk / fed and can yield /fed by 2.47 and 2.35 ton in 2015/2016 and 2016/2017 seasons , respectively.

Table 2. Average of number of millable cane (thousand/fed.) and cane yield (ton/fed.) as influenced by ridge widths, seeding and nitrogen rates as well as their interactions in 2015/2016 and 2016/2017 seasons.

\begin{tabular}{|c|c|c|c|c|c|c|c|c|c|c|c|c|c|c|c|c|c|}
\hline \multirow{4}{*}{$\begin{array}{l}\text { Ridge } \\
\text { widths } \\
\text { (cm) } \\
\text { (A) }\end{array}$} & \multirow{4}{*}{$\begin{array}{c}\text { Seeding } \\
\text { rates } \\
\text { (row/ } \\
\text { furrow) } \\
\text { B }\end{array}$} & \multicolumn{8}{|c|}{ No.of Millable cane (thousand/fed.) } & \multicolumn{8}{|c|}{ Cane yield (ton/fed.) } \\
\hline & & \multicolumn{4}{|c|}{ 2015/2016 season } & \multicolumn{4}{|c|}{ 2016/2017 season } & \multicolumn{4}{|c|}{ 2015/2016 season } & \multicolumn{4}{|c|}{ 2016/2017 season } \\
\hline & & \multicolumn{3}{|c|}{ Nitrogen kg/fed. (C) } & & \multicolumn{3}{|c|}{ Nitrogen kg/fed.(C) } & \multirow[b]{2}{*}{ Mean } & \multicolumn{3}{|c|}{ Nitrogen kg/fed. (C) } & \multicolumn{5}{|c|}{ Nitrogen kg/fed. (C) } \\
\hline & & 180 & 200 & 220 & Mean & 180 & 200 & 220 & & 180 & 200 & 220 & Mes & 180 & 200 & 220 & Mean \\
\hline \multirow{2}{*}{80} & 1.5 & 45.83 & 46.52 & 46.92 & 46.42 & 45.56 & 46.09 & 46.51 & 46.05 & 52.34 & 53.96 & 54.83 & 53.71 & 51.68 & 53.27 & 54.11 & 53.02 \\
\hline & 2.0 & 48.63 & 49.15 & 49.89 & 49.22 & 48.68 & 49.14 & 49.86 & 49.23 & 51.45 & 53.47 & 54.21 & 53.04 & 51.10 & 53.21 & 53.59 & 52.63 \\
\hline Mea & & 47.24 & 47.83 & 48.41 & 47.83 & 47.13 & 47.62 & 48.19 & 47.64 & 51.89 & 53.72 & 54.52 & 53.37 & 51.39 & 53.24 & 53.85 & 52.82 \\
\hline \multirow[b]{2}{*}{100} & 1.5 & 44.35 & 44.73 & 45.21 & 44.76 & 43.93 & 44.46 & 44.67 & 44.35 & 48.65 & 49.03 & 49.52 & 49.06 & 48.76 & 49.29 & 49.49 & 49.18 \\
\hline & 2.0 & 47.86 & 48.43 & 48.74 & 48.34 & 47.24 & 48.02 & 48.29 & 47.85 & 52.17 & 54.17 & 55.41 & 53.91 & 52.07 & 53.83 & 55.25 & 53.72 \\
\hline M & & 46.10 & 46.58 & 46.97 & 47.58 & 45.59 & 46.24 & 46.48 & 46.10 & 50.41 & 51.60 & 52.46 & 51.49 & 50.42 & 51.56 & 52.37 & 51.45 \\
\hline \multirow[b]{2}{*}{120} & 1.5 & 43.60 & 44.57 & 45.42 & 44.53 & 43.34 & 44.11 & 45.13 & 44.19 & 47.90 & 48.87 & 49.72 & 48.83 & 48.17 & 48.93 & 49.96 & 49.01 \\
\hline & 2.0 & 46.26 & 46.82 & 47.51 & 46.86 & 45.82 & 46.73 & 47.02 & 46.52 & 50.56 & 52.70 & 52.82 & 52.03 & 50.64 & 52.54 & 52.61 & 51.93 \\
\hline Mean & & 44.94 & 45.69 & 46.46 & 45.70 & 44.59 & 45.42 & 46.07 & 45.36 & 49.24 & 50.78 & 51.27 & 50.43 & 49.41 & 50.74 & 51.29 & 50.47 \\
\hline \multirow{2}{*}{$\begin{array}{l}\text { Average } \\
\text { of seeding } \\
\text { rates }\end{array}$} & 1.5 & 44.59 & 45.28 & 45.84 & 45.24 & 44.28 & 44.88 & 45.43 & 44.87 & 49.63 & 50.62 & 51.35 & 50.53 & 49.53 & 50.50 & 51.18 & 50.41 \\
\hline & 2.0 & 47.58 & 3.13 & 8.72 & 48.14 & 47.25 & 47.96 & 48.39 & 47.87 & 51.39 & 53.45 & 54.15 & 53.00 & 51.28 & 53.19 & 53.81 & 52.76 \\
\hline \multicolumn{2}{|c|}{ Mean of nitrogen } & 46.09 & 46.70 & 47.28 & & 45.77 & 46.43 & 46.91 & & 50.51 & 52.04 & 52.75 & & 50.58 & 51.85 & 52.50 & \\
\hline \multicolumn{18}{|c|}{ LSD at 0.5 level for: } \\
\hline \multirow{2}{*}{\multicolumn{2}{|c|}{$\begin{array}{l}\text { Ridge widths (A) } \\
\text { Seeding rates (B) }\end{array}$}} & & & & 0.1 & & & & 0.1 & & & & 0.2 & & & & 0.31 \\
\hline & & & & & 0.2 & & & & 0.1 & & & & 0.2 & & & & 0.26 \\
\hline \multicolumn{2}{|c|}{$\begin{array}{l}\text { Seeding rates }(B) \\
\text { Nitrogen rates } \\
\text { (C) }\end{array}$} & & & & 0.17 & & & & 0.22 & & & & 0.19 & & & & 0.15 \\
\hline \multirow{2}{*}{\multicolumn{2}{|c|}{$\begin{array}{l}\text { (A) } \times \text { (B) } \\
\text { (A) } \times(C)\end{array}$}} & & & & 0.3 & & & & 0.3 & & & & 0.2 & & & & 0.52 \\
\hline & & & & & NS & & & & NS & & & & 0.3 & & & & 0.37 \\
\hline \multicolumn{2}{|l|}{ (B) $x(C)$} & & & & NS & & & & NS & & & & 0.34 & & & & 0.31 \\
\hline \multicolumn{2}{|c|}{ (A) $x$ (B) $x(C)$} & & & & NS & & & & NS & & & & 0.52 & & & & 0.49 \\
\hline
\end{tabular}
$1.14)$ thousand in number millable canes/fed and cane yield (1.53 and 2.24) (1.27 and 1.92) ton/fed were obtained by supplying sugarcane with $200 \mathrm{~kg} \mathrm{~N} / \mathrm{fed}$ and $220 \mathrm{~kg} \mathrm{~N} / \mathrm{fed}$ first and second season, successively. These results are probably due to the increase of both stalk height and diameter as $\mathrm{N}$-level was raised (Table 1) which may be referred to the role of nitrogen as an essential element in building up plant organs. These results coincided with those given by Ismail, et al. (2008) and Mokadem, et al. (2008).

All the interactions had insignificant influence on number of millable canes/fed except that of ridge width $\mathrm{x}$ seeding rate, in both seasons. planting sugar cane plants on ridge of $80 \mathrm{~cm}$ and seeding rate of 2 rows of cane cuttings (16800 of three-budded cane cuttings/fed) produced the highest number of millable canes 49.22 and 49.23 thousand / fed, on the contrary, planting sugar cane plants on ridges of $120 \mathrm{~cm}$ width and seeding rate of 1.5 rows of cane cuttings ( 12600 of three-budded cane cuttings/fed) produced the lowest number of millable canes 44.53 and 44.19 respectively.

All possible interactions among the three studied factors had a significant influence on cane yield/fed in both seasons. planting sugar cane plants on ridge widths of 100 $\mathrm{cm}$ and seeding rate of 2 rows of cane cuttings ( 16800 of three-budded cane cuttings/fed) produced the highest cane yield/fed 53.91 and 53.72 ton , on the contrary , planting sugar cane plants on ridges of $120 \mathrm{~cm}$ width and seeding rate of 1.5 rows of cane cuttings ( 12600 of three-budded cane cuttings/fed) produced the lowest cane yield/fed 48.83 and 49.1 ton in 2015/2016 and 2016/2017 seasons, respectively.
Results recorded in Table 2 show clearly that there
were significant increases $(0.61$ and 1.19$)$ and $(0.66$ and compared with that recorded by applying $180 \mathrm{~N} / \mathrm{fed}$ in the thousand / fed in 2015/2016 and 2016/2017 seasons , 
The interaction effect among ridge widths and nitrogen fertilizer rates was significant on stalk height in both seasons. Sowing sugar cane plants on ridge of $100 \mathrm{~cm}$ width and received $220 \mathrm{~kg} \mathrm{~N} /$ fed. gave the highest cane yield/fed 54.52 and 53.85 ton, but the lowest cane yield/fed 49.24 and 49.41 ton was recorded with sowing plants on ridge width of $120 \mathrm{~cm}$ and fertilized by nitrogen at the rate of $180 \mathrm{~kg} \mathrm{~N} / \mathrm{fed}$. as compared with other treatments in 20915/2016 and 2016/2017 seasons , respectively.

The interaction effect among seeding rates and nitrogen fertilizer rates was significant on cane yield/fed in both seasons. Sowing sugar cane plants by seeding rate of 2.0 rows of cane cuttings (planting material 16800 of three-budded/setts) and received $220 \mathrm{~kg} \mathrm{~N} /$ fed. gave the highest cane yield/fed 54.15 and 53.81 ton, but sowing plants by seeding rate of 1.5 rows of cane cuttings and fertilized by nitrogen at the rate of $180 \mathrm{~kg} \mathrm{~N} / \mathrm{fed}$. gave the lowest cane yield/fed 49.63 and 49.53 ton as compared with other treatments in 20915/2016 and 2016/2017 seasons, respectively .

The interaction effect among ridge widths, seeding rates and nitrogen fertilizer rates was significant on cane yield / fed in both seasons. Sowing sugar cane plants on ridges of $100 \mathrm{~cm}$ width, seeding rate of 2.0 rows of cane cuttings (planting material 16800 of three-budded/setts) and received $220 \mathrm{~kg} \mathrm{~N} / \mathrm{Fed}$. gave the highest cane yield/fed 55.41 and 55.61 ton , on the other hand, sowing plants on ridge width of $120 \mathrm{~cm}$, seeding rate of 1.5 rows of cane cuttings and fertilized by nitrogen at the rate of 180 $\mathrm{kg} \mathrm{N} /$ fed. gave the lowest cane yield/fed 47.90 and 48.17 ton as compared with other treatments in 20915/2016 and 2016/2017 seasons, respectively .

5. Juice quality percentages and sugar yield /fed:

Data in Tables 3 and 4 show that increasing ridge width from 80 up to $100 \mathrm{~cm}$ caused a significant increase and gave the highest values of brix 22.45 and $22.90 \%$, sucrose 21.49 and $21.70 \%$, sugar recovery percentages 14.17 and $14.04 \%$ and sugar yield /fed 7.30 and 7.22 ton, while increasing ridge width from 100 up to $120 \mathrm{~cm}$ resulted in a significant reduction in the brix , sucrose, sugar recovery percentages and sugar yield/fed, in both seasons. These results are in agreement with those mentioned by Sundara (2003), Ismail, et al. (2008) and Mokadem, et al. (2008).

The results in Table 3 and 4 indicate that increasing planting materials from 1.5 to 2.0 rows of cane cuttings (from 12600 to 16800 of three-budded cane cuttings/fed) resulted in an appreciable increase in brix, sucrose, sugar recovery percentages and sugar yield/fed, in both seasons.

Nitrogen rates showed significant effects on brix, sucrose, sugar recovery percentages and sugar yield/fed, in both seasons. Gradual increases in brix, sucrose, sugar recovery percentages and sugar yield ton/fed values were noticed as nitrogen rate increased from 180 up to $200 \mathrm{~kg}$ $\mathrm{N} /$ fed. Thereafter, the additional nitrogen increment was not accompanied by an increase in brix, sucrose, sugar recovery percentages and sugar yield/fed, in both seasons. Similar results were observed by Mokadem, et al. (2008).

Brix, sucrose, sugar recovery percentages and sugar yield/fed were significantly affected by the interaction between ridge widths and seeding rates in both seasons. planting sugar cane plants on ridges of $100 \mathrm{~cm}$ width and seeding rate of 2 rows of cane cuttings ( 16800 of threebudded cane cuttings/fed) gave the highest values of brix 22.52 and 22.9 , sucrose 21.55 and $21.77 \%$, sugar recovery 14.20 and $14.07 \%$ and sugar yield /fed 7.66 and 7.56 ton compared to all other treatments in 2015/2016 and 2016/2017 seasons, respectively.

Table 3. Average of birx and sucrose percentage as influenced by ridge widths, seeding and nitrogen rates as well as their interactions in $2015 / 2016$ and $2016 / 2017$ seasons.

\begin{tabular}{|c|c|c|c|c|c|c|c|c|c|c|c|c|c|c|c|c|c|}
\hline \multirow{4}{*}{$\begin{array}{l}\text { Ridge } \\
\text { widths } \\
\text { (cm) } \\
\text { (A) } \\
\end{array}$} & \multirow{4}{*}{$\begin{array}{l}\text { Seeding } \\
\text { rates (row/ } \\
\text { furrow) B }\end{array}$} & \multicolumn{8}{|c|}{ Birx\% } & \multicolumn{8}{|c|}{ Sucrose\% } \\
\hline & & \multicolumn{4}{|c|}{$2015 / 2016$ season } & \multicolumn{4}{|c|}{$2016 / 2017$ season } & \multicolumn{4}{|c|}{$2015 / 2016$ season } & \multicolumn{4}{|c|}{$2016 / 2017$ season } \\
\hline & & Vitrog & $\mathrm{kg} / \mathrm{f}$ & ed. (C) & & Nitrog & $\mathrm{eng} / \mathrm{f}$ & ed. (C) & & Nitrog & $\operatorname{sen~} \mathrm{kg} / \mathrm{t}$ & ed. (C) & & Nitrog & $\operatorname{sen~kg/1~}$ & fed. (C) & \\
\hline & & 180 & 200 & 220 & ean & 180 & 200 & 220 & Me: & 180 & 200 & 220 & $\mathbf{M e}$ & 180 & 200 & 220 & ve \\
\hline \multirow{2}{*}{80} & 1.5 & 20.57 & 21.61 & 21.21 & 21.12 & 21.00 & 22.05 & 21.64 & 21.56 & 19.26 & 20.40 & 19.97 & 19.88 & 19.61 & 20.79 & 20.39 & 20.26 \\
\hline & 2.0 & 21.57 & 22.99 & 21.57 & 22.04 & 22.01 & 23.44 & 22.01 & 22.49 & 20.45 & 22.18 & 20.35 & 20.99 & 20.79 & 22.33 & 20.74 & 21.28 \\
\hline Mean & & 21.07 & 22.30 & 21.39 & 21.58 & 21.51 & 22.74 & 21.83 & 22.02 & 19.85 & 21.29 & 20.16 & 20.43 & 20.20 & 21.57 & 20.56 & 20.78 \\
\hline \multirow{2}{*}{100} & 1.5 & 21.92 & 23.18 & 22.05 & 22.38 & 22.36 & 23.63 & 22.50 & 22.83 & 20.85 & 22.40 & 21.03 & 21.43 & 21.14 & 22.57 & 21.21 & 21.64 \\
\hline & 2.0 & 21.70 & 23.07 & 22.79 & 22.52 & 22.14 & 23.53 & 23.24 & 22.97 & 20.57 & 22.23 & 21.84 & 21.55 & 20.89 & 22.44 & 21.99 & 21.77 \\
\hline Mean & & 21.81 & 23.13 & 22.42 & 22.45 & 22.25 & 23.58 & 22.87 & 22.90 & 20.72 & 22.32 & 21.43 & 21.49 & 21.01 & 22.50 & 21.60 & 21.70 \\
\hline \multirow{2}{*}{120} & 1.5 & 21.92 & 23.07 & 22.36 & 22.45 & 22.36 & 23.53 & 22.81 & 22.90 & 20.82 & 22.16 & 21.34 & 21.44 & 21.15 & 22.44 & 21.43 & 21.67 \\
\hline & 2.0 & 21.88 & 22.84 & 22.23 & 22.32 & 22.32 & 23.29 & 22.67 & 22.76 & 20.79 & 21.89 & 21.21 & 21.30 & 21.07 & 22.22 & 21.44 & 21.58 \\
\hline Mean & & 21.90 & 22.95 & 22.29 & 22.38 & 22.34 & 23.40 & 22.73 & 22.83 & 20.81 & 22.03 & 21.27 & 21.37 & 21.11 & 22.33 & 21.44 & 21.63 \\
\hline \multirow{2}{*}{$\begin{array}{l}\text { Average of } \\
\text { seeding } \\
\text { rates }\end{array}$} & 1.5 & 21.47 & 22.63 & 21.87 & 21.99 & 21.91 & 23.07 & 22.31 & 22.43 & 20.31 & 21.65 & 20.78 & 20.91 & 20.63 & 21.93 & 21.01 & 21.19 \\
\hline & 2.0 & 21.72 & 22.96 & 22.20 & 22.30 & 22.16 & 23.41 & 22.64 & 22.74 & 20.60 & 22.10 & 21.13 & 21.28 & 20.92 & 22.33 & 21.39 & 21.54 \\
\hline \multicolumn{2}{|c|}{ Mean of nitrogen } & 21.59 & 22.80 & 22.03 & & 22.03 & 23.25 & 22.48 & & 20.46 & 21.88 & 20.95 & & 20.78 & 22.13 & 21.20 & \\
\hline \multicolumn{18}{|c|}{ LSD at 0.5 level for: } \\
\hline \multirow{2}{*}{\multicolumn{2}{|c|}{$\begin{array}{l}\text { Ridge widths (A) } \\
\text { Seeding rates (B) }\end{array}$}} & & & & 0.05 & & & & 0.06 & & & & 0.08 & & & & 0.04 \\
\hline & & & & & 0.11 & & & & 0.12 & & & & 0.14 & & & & 0.14 \\
\hline \multicolumn{2}{|c|}{ Nitrogen rates $(C)$} & & & & 0.25 & & & & 0.28 & & & & 0.33 & & & & 0.27 \\
\hline \multicolumn{2}{|l|}{ (A) $x$ (B) } & & & & 0.26 & & & & 0.22 & & & & 0.31 & & & & 0.24 \\
\hline \multirow{2}{*}{\multicolumn{2}{|c|}{$\begin{array}{l}\text { (A) } \times(C) \\
\text { (B) } \times(\text { (C) }\end{array}$}} & & & & NS & & & & NS & & & & NS & & & & NS \\
\hline & & & & & NS & & & & NS & & & & NS & & & & NS \\
\hline \multicolumn{2}{|c|}{ (A) $x(B) \times(C)$} & & & & NS & & & & NS & & & & 0.82 & & & & NS \\
\hline
\end{tabular}


Table 4. Average of sugar recovery and sugar yield (ton/fed.) as influenced by ridge widths, seeding and nitrogen rates as well as their interactions in $2015 / 2016$ and $2016 / 2017$ seasons.

\begin{tabular}{|c|c|c|c|c|c|c|c|c|c|c|c|c|c|c|c|c|c|}
\hline \multirow{4}{*}{$\begin{array}{l}\text { Ridge } \\
\text { widths } \\
\text { (cm) } \\
\text { (A) }\end{array}$} & \multirow{4}{*}{$\begin{array}{c}\text { Seeding } \\
\text { rates (row/ } \\
\text { furrow) } \\
\text { B }\end{array}$} & \multicolumn{8}{|c|}{ Sugar recovery\% } & \multicolumn{8}{|c|}{ Sugar yield (ton/fed) } \\
\hline & & \multicolumn{4}{|c|}{ 2015/2016 season } & \multicolumn{4}{|c|}{ 2016/2017 season } & \multicolumn{4}{|c|}{ 2015/2016 season } & \multicolumn{4}{|c|}{ 2016/2017 season } \\
\hline & & \multicolumn{3}{|c|}{ Nitrogen kg/fed. (C) } & \multirow{2}{*}{ Mean } & \multicolumn{3}{|c|}{ Nitrogen kg/fed. (C) } & \multirow{2}{*}{ Mean } & \multicolumn{3}{|c|}{ Nitrogen kg/fed. (C) } & \multirow{2}{*}{ Mean } & \multicolumn{3}{|c|}{ Nitrogen kg/fed. (C) } & \multirow{2}{*}{ Mean } \\
\hline & & 180 & 200 & 220 & & 180 & 200 & 220 & & 180 & 200 & 220 & & 180 & 200 & 220 & \\
\hline \multirow{2}{*}{80} & 1.5 & 12.61 & 13.36 & 13.10 & 13.03 & 12.70 & 13.47 & 13.25 & 13.14 & 6.60 & 7.21 & 7.18 & 7.00 & 6.56 & 7.18 & 7.17 & 6.97 \\
\hline & 2.0 & 13.46 & 14.69 & 13.32 & 13.82 & 13.50 & 14.46 & 13.43 & 13.80 & 6.92 & 7.85 & 7.22 & 7.33 & 6.90 & 7.70 & 7.20 & 7.26 \\
\hline Mean & & 13.04 & 14.03 & 13.21 & 13.42 & 13.10 & 13.96 & 13.34 & 13.47 & 6.76 & 7.54 & 7.20 & 7.16 & 6.73 & 7.43 & 7.18 & 7.11 \\
\hline \multirow{2}{*}{100} & 1.5 & 13.73 & 14.83 & 13.86 & 14.14 & 13.69 & 14.63 & 13.69 & 14.00 & 6.68 & 7.27 & 6.86 & 6.94 & 6.68 & 7.21 & 6.78 & 6.89 \\
\hline & 2.0 & 13.53 & 14.70 & 14.39 & 14.20 & 13.55 & 14.52 & 14.16 & 14.07 & 7.06 & 7.96 & 7.97 & 7.66 & 7.06 & 7.82 & 7.82 & 7.56 \\
\hline Mean & & 13.64 & 14.77 & 14.13 & 14.17 & 13.62 & 14.58 & 13.93 & 14.04 & 6.87 & 7.62 & 7.41 & 7.30 & 6.87 & 7.52 & 7.29 & 7.22 \\
\hline \multirow{2}{*}{120} & 1.5 & 13.70 & 14.61 & 14.05 & 14.11 & 13.71 & 14.52 & 13.77 & 14.00 & 6.56 & 7.14 & 6.99 & 6.89 & 6.61 & 7.11 & 6.88 & 6.86 \\
\hline & 2.0 & 13.68 & 14.42 & 13.98 & 14.03 & 13.65 & 14.43 & 13.88 & 13.98 & 6.92 & 7.60 & 7.38 & 7.30 & 6.91 & 7.58 & 7.30 & 7.26 \\
\hline Mean & & 13.69 & 14.51 & 14.01 & 14.07 & 13.68 & 14.48 & 13.82 & 13.99 & 6.74 & 7.37 & 7.18 & 7.10 & 6.76 & 7.35 & 7.09 & 7.06 \\
\hline \multirow{2}{*}{$\begin{array}{l}\text { Average of } \\
\text { seeding } \\
\text { rates }\end{array}$} & 1.5 & 13.35 & 14.27 & 13.67 & 13.76 & 13.37 & 14.21 & 13.57 & 13.71 & 6.62 & 7.22 & 7.02 & 6.95 & 6.62 & 7.17 & 6.95 & 6.91 \\
\hline & 2.0 & 13.55 & 14.61 & 13.89 & 14.02 & 13.56 & 14.47 & 13.82 & 13.95 & 6.97 & 7.81 & 7.52 & 7.43 & 6.95 & 7.70 & 7.44 & 7.36 \\
\hline \multicolumn{2}{|c|}{ Mean of nitrogen } & 13.45 & 14.43 & 13.78 & & 13.47 & 14.34 & 13.69 & & 6.79 & 7.51 & 7.27 & & 6.81 & 7.43 & 7.19 & \\
\hline \multicolumn{18}{|c|}{ LSD at 0.5 level for: } \\
\hline \multirow{2}{*}{\multicolumn{2}{|c|}{$\begin{array}{l}\text { Ridge widths (A) } \\
\text { Seeding rates (B) }\end{array}$}} & & & & 0.07 & & & & 0.07 & & & & 0.07 & & & & 0.05 \\
\hline & & & & & 0.12 & & & & 0.10 & & & & 0.05 & & & & 0.06 \\
\hline \multicolumn{2}{|c|}{ Nitrogen rates (C) } & & & & 0.19 & & & & 0.22 & & & & 0.12 & & & & 0.10 \\
\hline \multicolumn{2}{|l|}{ (A) $x$ (B) } & & & & 0.21 & & & & 0.18 & & & & 0.14 & & & & 0.13 \\
\hline \multicolumn{2}{|l|}{ (A) $\times(C)$} & & & & NS & & & & NS & & & & NS & & & & NS \\
\hline \multicolumn{2}{|l|}{ (B) $x(C)$} & & & & NS & & & & NS & & & & NS & & & & NS \\
\hline \multicolumn{2}{|c|}{ (A) $\times(B) \times(C)$} & & & & 0.51 & & & & NS & & & & 0.32 & & & & 0.36 \\
\hline
\end{tabular}

Brix, sucrose, sugar recovery percentages and sugar yield ton/fed were not significantly affected by the interaction between ridge widths $\mathrm{x} \mathrm{N}$ rates and interaction between seeding rates $\mathrm{x} \mathrm{N}$ rates in both seasons.

The $2^{\text {nd }}$ order interaction among the three studied factors had a significant influence on sucrose $\%$ and sugar recovery $\%$ in first season as well as on sugar yield/fed in both seasons. Sowing sugar cane plants on ridges of 100 $\mathrm{cm}$ width, seeding rate of 2.0 rows of cane cuttings (planting material 16800 of three-budded/setts) and received $220 \mathrm{~kg} \mathrm{~N} /$ fed gave the highest sugar yield/fed 7.79 and 7.82 ton as compared with other treatments in 20915/2016 and 2016/2017 seasons, respectively .

Generally, it could be recommended that sowing promising sugarcane variety G. 2003-49 on ridges_of 100 $\mathrm{cm}$ width, seeding rate of 2.0 rows of cane cuttings (planting material 16800 of three-budded/setts) and received $220 \mathrm{~kg} \mathrm{~N} /$ fed gave the highest cane and sugar yield/fed. under s Sohag Governorate condition.

\section{REFERENCES}

Ahmed A.Z.(2003) Assessment of the optimum nitrogen level and seed rate for two promising sugarcane varieties. Egypt. J. Appl. Sci., 18 (6B): 559-573.

Arnold, K. (1986). Methods of soil analysis, physical methods. Second America, Inc. Madison Wisconsin.

Association of Official Agricultural Chemist (1995). Official Methods of Analysis puplished by the A.O.A.C., Box 540, Washington.

Abd El-Aal, A.M.; S.R.E. El Shiekh and M.A. Fergany (2015). Ratooning ability of some sugarcane promising varieties under different levels of nitrogen fertilization. Egypt. J. Appl. Sci., 30 (1): 23-34.
Avtar, S. (2000). Influence of seed rate and row spacing on the growth and yield of late planted sugarcane. Sugar Tech., 2(3): 49-50

Azzazy, N.B.; A.M.A. El-Shafai and A.M. Abd El-Aal (2005). Performance of some promising plant and first ratoon sugarcane varieties under different nitrogen levels. Egypt. J. Agric. Sci., 20 (8-A):6578.

Bekheet, M.A.; N.M.S. Shalaby and M.M. Ibrahim (2011): Effect of row spacing and nitrogen fertilization on yield and quality of two sugarcane varieties, Fayoum J. Agric. Res. \& Dev., 25(2):112-127

El-Geddawy, I.H. Dalia; B.S. Makhlouf and M.A. Bekheet (2015). Performance of some sugarcane promising varieties under different seed sett rates and potassium fertilization. International $\mathrm{J}$. of Curr. Microbiol. App. Sci. 4(11): 92-110

El-Geddawy, I.H.; D.G. Darweish; A.A. El-Sherbiny and E.E.A. El-Hady (2002-b). Effect of row spacing and number of buds/seed setts on 1- growth characters of first ratoon crops for some sugar cane varieties. Pakistan Sugar J., 17 (3): 7-14.

El-Geddawy, I.H.; G.G. Darweish; A.A. El-Sherbiny and E.E.A. El-Hady (2002-a). Effect of row spacing and number of buds/seed setts on 3-yield component of ratoon crops for some sugar cane varieties ratoon. Pakistan Sugar J., 17 (2): 2-8.

El-Shafai, A.M.A. and A.M.A. Ismail (2006). Effect of row spacing on yield and quality of some promising sugarcane varieties. Egypt. Appl. Sci., 21 (11): 32-46.

El-Sogheir, K.S. (1999). Levelling, planting and harvesting of sugarcane under traditional and mechanical methods. Ph.D. Thesis, Fac. Agric. Minia Univ., Egypt. 
Garside, A.-L., M.J. Bell; J.E. Berthelsen and N.V. Halpin (2002). Effect of fumigation, density and row spacing on the growth and yield of sugarcane in two diverse environments. Sugar Cane International, (Nov/Dec.): 19-26.

Ismail, A.M.A.; M.A. Bekheet and A.S. Abo El-Hamd. (2008). Yield and quality of four sugarcane varieties as influenced by seed rate and nitrogen fertilization. Egypt. J. Appl. Sci., 23 (1): 107-123.

Mokadem, Sh.A.; S.A.A. AtaAllah; M.A Bekheet and A.F.I. Gadalla (2008). Effect of sources, levels and number of applications of nitrogen fertilizer on yield and quality of sugar cane. Minia J. Agric. Res., Develop., 28 (4): 767-783.

Pag, A.L.(1982). Chemical and microbiological properties. Amwrican Society of Agron., Inc. Soil Sci. Society of America, Inc. Madison Wisconsin.

Raskar, B.S. and P.G. Bhoi (2003). Yield attributes of sugarcane as influenced by intra-row spacings, fertilizer levels and planting materials. Indian Sugar, 53 (5): 327-331.

Rizk, T.Y.; M.H. El-Agroudy; I.H. El-Geddawy and M.A. Fergany (2004-a). Effect of row spacing and cutting size on cane juice quality attributes. Egypt. J. Agric. Res., 82 (1): 251-262.

Rizk, T.Y.; M.H. El-Agroudy; I.H. El-Geddawy and M.A. Fergany (2004-b). Effect of row distance and cutting size on growth criteria of two promising sugar cane varieties and the commercial variety. Egypt. J. Agric. Res., 82 (1): 263-276.
Shafshak, S.A.; I.H. El-Geddawy; S.A.H. Allam and G.S. El-Sayed (2001). Effect of planting densities and nitrogen fertilizer on: 1. Growth criteria, juice quality and chemical constituents of some sugar cane varieties. Pakistan Sugar J., 16(4): 2-11.

Shahid, B.;M-Z. Khan and A. Naeem (2002). Yield and quality of sugarcane as influenced by inter row spacing and seed rate. Pakistan-Sugar-Journal., 17(4): 7-9.

Snedecor, G.W. and W.G. Cochran (1981). Statistical Methods. Seventh Ed. Iowa State Univ. Press, Ames, Iowa, USA.

Sundara, B. (2003). Response of new sugarcane varieties to wide row spacing. Proc. $65^{\text {th }}$ Ann. Convention Sugar Technol. Assoc India, Bhubaneshwar, Orissa, India, 22024, Aug., 2003: A 168-A 177. Record 768 of 772 - CAB Absts 2003/ 11- 2004/ 04

Tiwari, T.N.; S. Sharma.; S.B. Singh and D.N. Singh (2004). Performance of sugarcane varieties with varying nitrogen levels under summer planting conditions of Bhat soils. Indian Sugar, 54 (9): $727-732$

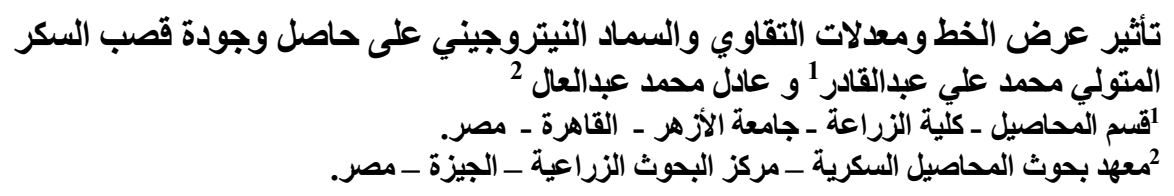

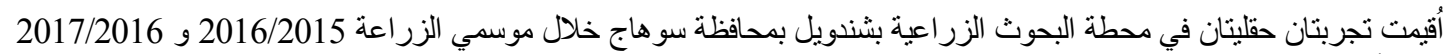

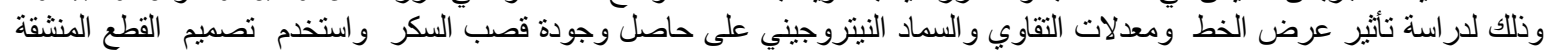

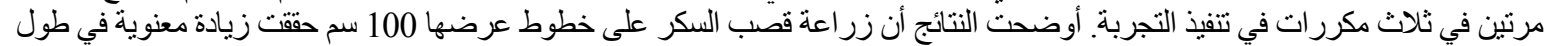

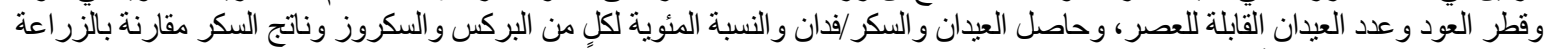

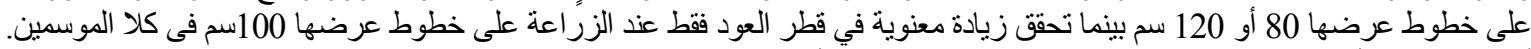

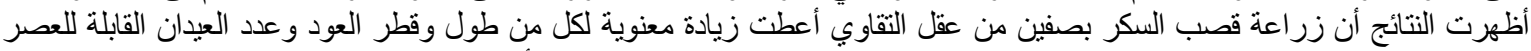

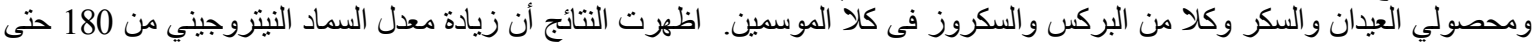

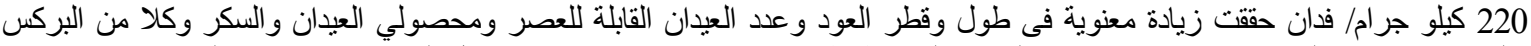

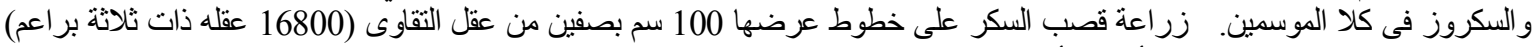

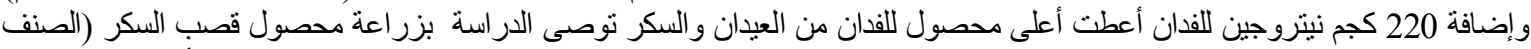

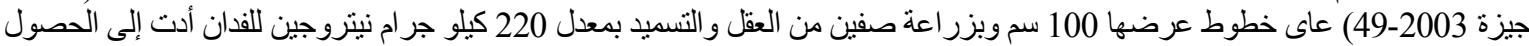
على أعلى حاصل من العيدان و السكر/فدان تحت ظروف مات محافظه سوهاج . 